\title{
Abuse of Dominant Position by Refusing to Issue Copyright Licenses
}

Pallavi Khanna*

\section{Abstract}

The aim of the paper is to analyze when firms abuse their dominant position, specifically with respect to refusing to issue copyright licenses. The objective is to understand what is meant by abuse by a dominant enterprise and view how different jurisdictions such as the United States (US) and European Union (EU) have dealt with the same, in order to examine the ability of the Indian legal framework to handle such cases. The scope of the paper is limited to providing a comparative analysis of the EU and US and attempts to apply the same to India. This paper seeks to explore whether competition law and intellectual property law intersect with each other and seeks to examine when dominant conduct can be regarded as abusive. The paper also scrutinizes how the US and EU courts have dealt with cases of denial of IPR license and whether the Indian scenario is well equipped to effectively handle cases of refusal to license.

Keywords: Abuse of Dominance, Article 82 of European Communities Treaty (ECT), Competition Act, 2002, Essential Facilities Doctrine, Section 2 of Sherman Act, 1890

\section{Introduction}

Competition law and IPR intersect when it comes to ensuring an equilibrium between market access and safeguarding

\footnotetext{
*Associate at The Guild Advocates \& Associate Counsel, New Delhi, India; pallavi.nls17@gmail.com
} 
innovation. ${ }^{1}$ Competition law seeks to ensure that there are uniform standards of growth for all actors operating in the market. However, the extent of power exercised by all the actors is not always the same and this means that some gain a dominant position vis-a-vis others. While being in this dominant position is not prejudicial to competition, it is a cause of concern for the competition regulation authorities.

The common perception is that antitrust legislations safeguard competition, while IP law rewards innovation to incentivize creation of new products in the market. The common focus of the two fields of law is to enhance technical progress for the ultimate benefit of consumers. The forces operating in the market would be more open to experiments and to innovate if they are assured of no free riders and if they are faced with strong competition. Hence IPR excludes competition by imitation and promotes competition through substitution. As can be observed in IMS Health ${ }^{2}$, competition law seeks to afford protection to those keen to introduce new products in the market and are unable to do so without grant of licenses. It does not safeguard those who attempt to imitate the existing products, as reflected in Magill3.The refusal to issue IPR licenses is not, per se, anti-competitive since an obligation to do so would restrict the exclusivity granted to IPR owners. ${ }^{4}$ At the same time, dominant firms cannot be allowed to create monopolies over the market by exercising control over ancillary markets. In some cases, an effective regime of IPR affords enterprises with dominance in the relevant markets. The potential of dominance which IPR provides has increased with the growth of new technologies. The TRIPs agreement also recognizes the intersection of IPR and competition law by allowing its members to

1 Copyright, Competition and Development, REPORT BY THE MAX PLANCK INSTITUTE FOR INTELLECTUAL.

2 IMS Health GmbH \& Co OHG v NDC Health GmbH \& CoKG (C418/01) [2004] E.C.R. I-5039 (ECJ (5th Chamber).

3 Radio Telefis Eireann (RTE) and Independent Television Publications Ltd (ITP) v. Commission, Joined Cases C-241/91 P \& C-242/91 P, 1995 E.C.R. I-743.

${ }^{4}$ Microsoft v Commission, T 201/04 Section 289. 
make laws restraining anti-competitive practices of licensing which may be an abuse of IPR.

Denying access to crucial IPRs to competitors and other players in the market has emerged as a serious concern in the technology sector. The question which forms the focus of the debate is the extent to which the dominant IP owners must be permitted to exercise their prerogatives. This is important to ascertain when it may be regarded as abuse and when the owner of the IPR is required to share the right with others. The researcher seeks to carry out the analysis in the context of India, after comparing the approaches in the EU and US. It is seen that though there are some common traits between the EU and US approach, the US generally tends to favor IPR over other competition related concerns. The EU, however, has created an approach where, in exceptional circumstances, the refusal to license amounts to abuse of dominance. India can gain from how the EU and US have dealt with cases of refusal and incorporate the best practices from the international framework, in its approach. The researcher begins with a brief introduction about what constitutes abuse of dominance and then engages in a comparative analysis of the EU, US and India.

\section{Abuse of Dominance}

Abuse of dominance takes place when the IPR holder's refusal to issue license inordinately hampers competition in the market. Dominance occurs where a company is in a strong position of control over a certain market and it is able to act without considering the behaviours or effects on customers or competitors. Dominance of an enterprise can be ascertained by several factors such as market share, resources, size of competitors, dependence of consumers, source of dominant position, entry barriers, etc. ${ }^{5}$ When technical knowledge is restricted from being shared with other firms, it constitutes abuse of dominance, since the IPR is used to

${ }^{5}$ Directorate for Financial and Enterprise Affairs Competition Committee, Roundtable on Safe Harbours and Legal Presumptions in Competition Law Note by India , 6, available at https://one.oecd.org/ document/ DAF/ COMP/WD(2017)58/en/pdf . 
deter access to information and prevent the development of market, by curtailing growth of alternate supply chains, which results in restricted access. Dominance occurs under two circumstances - one, where some undertakings are in a superior position in a market with some amount of effective competition existing. IP law confers market power in a way by creating barriers to entry for competitors offering the same good or even its substitutes. The extent of market power is contingent on how efficiently the competitive products are kept out of the market Second, where there is a de facto monopoly and the competitor has no alternatives in terms of competition. In cases where the ownership of IP takes place in conjunction with de facto monopoly over the market which is adequate to justify dominance, then the ownership itself can confer dominance.

However, the mere fact that an IP protected product falls within the ambit of a de facto monopoly and hence within the scope of Section 2 of the Sherman Act, 1890, which states that: 'Every person who shall monopolize, or attempt to monopolize, or combine or conspire with any other person or persons, to monopolize any part of the trade or commerce among the several States, or with foreign nations, shall be deemed guilty of a felony.' ${ }^{6}$ or Article 82 of the European Community (EC)Treaty, which states that: 'any abuse by one or more undertakings of a dominant position within the common market or in a substantial part of it shall be prohibited as incompatible with the internal market in so far as it may affect trade between Member States. ${ }^{\prime 7}$.This by itself cannot be termed as abusive, as a firm achieves such monopoly on account of its investments in IP and R\&D, and is usually entitled to continue competing through its exclusionary rights in aftermarkets as well. Merely having a dominant position cannot be regarded as abuse. Abuse occurs when the enterprise in a dominant position behaves in a way which influences the market structure, by way of distortion of competition. At times, the refusal to issue licenses also restricts the competition in downstream markets. The refusal to license not only manifests in the market of the product or service, but it also acts a tool for obtaining leverage and protecting itself

615 U.S. Code $\S 2$.

${ }^{7}$ Art. 82 of the EC Treaty. 
from competitive forces in other markets. Such conduct can be abusive, if the firm which has economic advantage, because of its dominant position in one market, uses this to gain commercial advantage in adjacent markets. ${ }^{8}$

Dominant position refers to the economically strong position of an undertaking that allows it to distort effective competition in the relevant market by enabling it to act independent of other actors. 9 This doctrine was expanded in Hoffman-La Roche ${ }^{10}$ where the European Court of Justice (ECJ) noted that such a position doesn't imply that competition is precluded like in cases of monopoly but permits the undertaking profiting by it to have significant influence on the market conditions under which the competition develops. The case also acknowledged that though there are several factors to determine dominance of a firm, apart from a large market share, there are other important criteria such as the technology lead, developed sales network, absence of competition, etc.

Some abuses, though not listed under Article 82, still qualify as an abuse. For instance, refusal to deal with competitors or refusal to supply or license are also read into the scope of Article 82 by courts as abuse. While refusal to supply is linked to tangible property, refusal to license is related to IPR. The remedy available for abusive refusals to license, is the imposition of compulsory licensing on IPR holders. ${ }^{11}$

${ }^{8} \mathrm{H}$. Apostolopoulos, Refusal-to-Deal Cases of IP Rights at the Aftermarket in the US and EU Law: Converging of Both Law Systems Through Speaking the Same Language of Law and Economics,7, CHICAGO-KENT JOURNAL OF INTERNATIONAL AND COMPARATIVE LAW144-148 (2007).

9 Case 27/76 United Brands Company and United Brands Continentaal BV v Commission [1978] ECR207, Abuse of Dominant Position in Light of Legal Principles and Case Laws in the EC, 13, OFFICE FOR COMPETITION AND CONSUMER PROTECTION, Warsaw (2003).

10 Hoffmann-La Roche \&. Co. AG v Commission [1979] ECR 461 as cited in G. Monti, The Concept of Dominance under Article 82, available at https://www.lse.ac.uk/collections/law/staff\%20publications \%20full \%20text/monti/ECJdominancepaper.pdf.

11 E. Derclaye, Abuses of dominant position and intellectual property rights: a suggestion to reconcile the Community courts case law, KLUWER LAW INTERNATIONAL, 689 (2003). 


\section{The EU Perspective}

The EU law addresses the intersection between IPR and competition law vide Article 82 of the EC which states that competition law can act only in exceptional circumstances to restrict the lawful use of IPR. The Volvo12 judgement which held that the refusal to license a right by itself doesn't amount to abuse of dominance, still remains as a valid legal principle with respect to the application of Article 82 of the EC. The court reiterated that the mere refusal to license, though may seem selfish and unjustified, is not enough to constitute abuse of dominance and it should be coupled with other factors to be regarded as abuse, such as unfair pricing, stopping production of products in demand, etc. Hence, the EU law deviates from the balance between IPR and competition in favor of the latter, but only in exceptional circumstances and the general rule remains that IPR must be enforced.

The exceptional conditions where refusal is seen as abuse of market power is when the said refusal has the effect of eliminating all competition in the relevant market, when it is not backed by any legitimate justification and when the products are indispensable and has no substitutes. ${ }^{13}$ In the Magill case ${ }^{14}$ it was pointed out that a refusal to deal when unjustified, will be anti-competitive, if the owner holds an essential facility or a dominant company reserves a secondary downstream market for itself. Here the downstream market became relevant because there was a vertical link between the copyrighted product and the new product and the refusal hampered the competition in the downstream market as well. Hence, there was a duty to issue license. This case was crucial in bringing to light the fact that firms should not try to extend their monopoly to other markets by exercising their IPR. The test of indispensability of the product in the downstream market, effect on

12 AB Volvo v Erik Veng (UK) Ltd [1988] EUECJ C-238/87.

13 Oscar Bronner GmbH \& Co. KG v. Mediaprint Zeitungs- und Zeitschriftenverlag GmbH \& Co. KG,Case C-7/97, 1998 E.C.R. I-7791.

14 Radio Telefis Eireann (RTE) and Independent Television Publications Ltd (ITP) v. Commission, Joined Cases C-241/91 P \& C-242/91 P, 1995 E.C.R. I-743. 
competition in the relevant market and restriction on developing new products were some of the factors espoused in this case.

In Ladbroke ${ }^{15}$, the 'new product' condition was further refined and it was noted that the refusal to license infringes Article 82 only when the new product being prevented from introduction, is that which has a constant, regular and specific potential demand. It went on to add another restriction as per which the refusal contravenes Article 82 , if the product in question is essential for that activity and there are no substitutes available in the market. The Bronner Case 16 prescribed a tripartite test which combined the test in Magill and Ladbroke, by requiring indispensability, absence of justification, and elimination of competition as the conditions for determining abuse. The IMS Case ${ }^{17}$ also followed the standard laid down by Bronner.

In the case of Microsoft 18 , an 'entirety of circumstances' approach has been adopted which focused on the total factual circumstances surrounding the refusal, rather than a checklist of conditions. The licenses, where refusal amounts to limiting technical development, which prejudicially affects consumers, also works as a test to determine if abuse has taken place or not. The Microsoft cases were based on Article 82 of the European Communities Treaty (ECT), which pertains to abuse of dominance. In the first Microsoft case of 2004, a need was felt to pierce the veil of IPR to prevent Microsoft from using the guise of IPR, to avoid sharing information needed to develop products compatible with Windows. Hence the exercise of IPR was disregarded as an objective justification in cases where exceptional circumstances were established. It was further noted that tying in the windows media player acts as a shield from competing efficient vendors and hence amounted to abuse of dominant position, by refusing to supply information to competitors for bringing new products. In 2007, when the matter was brought before the Court of First Instance, reference was made

15 Tierce Ladbroke SA v. Commission, Case T-504/93, 1997 E.C.R. II-923, 5 C.M.L.R. 309 (1997) (Ct. First Instance).

16 Oscar Bronner $\mathrm{GmbH}$ \& Co. KG v. Mediaprint Zeitungs- und Zeitschriftenverlag GmbH \& Co. KG,Case C-7/97, 1998 E.C.R. I-7791.

17 IMS Health GmbH \& Co OHG v NDC Health GmbH \& CoKG(C418/01) [2004] E.C.R. I-5039 (ECJ (5th Chamber).

18 Case T201/04, Microsoft Corp v Commission, 2007 ECR II03601. 
to the four pronged test of indispensability, new product requirement, objective justification and exclusion of competition in secondary market, in order to establish that refusal was an abuse. It went on to hold that complementary products did constitute separate products for the purpose of Article 82 of the ECT. Emphasis was on whether the refusal to license would reduce the incentives to innovate in the industry as a whole and it was concluded that in this particular case, nondisclosure would hamper innovation because of lack of competitive pressures. The essential facilities doctrine operates when a product is indispensable for competitors and other firms are unable to stay without it in the market. ${ }^{19}$ Hence the competitor's products must be inter-operating with the product of the dominant undertaking in the main market, in order to categorize the product as being indispensable. The upstream product must be indispensable for the product in the downstream market and a refusal by a dominant firm in the former, should have the adverse effect of eliminating competition in the latter. ${ }^{20}$

IMS Health ${ }^{21}$ recognized conditions where compulsory licensing may be imposed. It was noted that compulsory licensing is valid when the refusal to license prevents the growth of a secondary market which adversely effects consumers. The refusal was held to be abusive only if the agency seeking IP does not wish to limit itself to mere duplication of goods and services offered in the secondary market by the IPR owner, but seeks to offer new products with potential demand in the market. This case was also pertinent in liberalizing the new product rule since it did not require the products to be different in character or meet specific needs of the consumer, but rather allowed improvements in existing traits to also be classified as new products. This case also clarified that dominant enterprises having control over indispensable inputs must facilitate the development of products which are its

19 OECD Policy Roundtables, The Essential Facilities Concept, http:// www.oecd.org/competition/abuse/1920021.pdf.

${ }^{20} \mathrm{Id}$.

21 IMS Health GmbH \& Co OHG v NDC Health GmbH \& CoKG(C418/01) [2004] E.C.R. I-5039 (ECJ (5th Chamber). 
competitors. In IMS Health Case22, while ascertaining if developing a similar database was essential, it was held that the improved database was being used by IMS health for restricting competition and hence it amounts to abuse of dominance. The court emphasized that even though there is no general duty to issue licenses, the exceptional circumstances may mandate access to refuse IP such as bar on emergence of new product with potential demand, lack of justification for refusal, exclusionary effect on competition in secondary market. The focus of this decision was on the promoting of access and openness to facilitate competition in the market when- i) the product is crucial for certain business, ii) the refusal excludes competition in the secondary market, iii) prevents the emergence of a new product which has potential demand from consumers, iv) there is no objective justification behind it.

\section{The US Approach}

In US, refusal to license does not imply misuse of Intellectual Property Rights, hence copyright owner may refuse to license its copyright. ${ }^{23}$ The US has witnessed a history of cases of compulsory licensing in the event of refusal to license. The duty to license arises only if there is a dominant enterprise which acts in an anticompetitive manner in refusing to issue license. The behavior is analyzed keeping in mind the effect on competition, business justification and extension of monopoly to other markets. In addition to this, unlawful tie-in sales and holder entering into litigation to harm business, are also actors which qualify as being anti-competitive. Refusal to license by a dominant enterprise has been regarded as unlawful exclusionary conduct. A valid rebuttal to the business justification of refusal is that the IP was acquired unlawfully. ${ }^{24}$

22 IMS Health GmbH \& Co OHG v NDC Health GmbH \& CoKG (C418/ 01) [2004] E.C.R. I-5039 (ECJ (5th Chamber).

${ }^{23}$ Orson Inc. v. Miramax Film Corp., 189 F.3d 377 (3d Cir. 1999).

${ }^{24}$ Data General Corporation v. Grumman Systems Support Corporation , 36 F.3d 1147 (1st Cir. 1994). 
Verizon $^{25}$ established that mere position of dominance and high pricing is lawful as well as a function of the free market economy as long as it is not anti-competitive. The focus was on the freedom of the firm to act or use its property in any way it chooses, hence preventing intervention of the courts in determining the dealings. The refusal to license extends to cover refusal to existing IPR holders as well by alteration of terms of license. Even then, the intention to monopolize is not an adequate reason to regard it as refusal and there must be some adverse effect on competition also. ${ }^{26}$

The Antitrust-IP Guidelines, also known as the DOJ-FTC Guidelines for licensing, emphasize on the rule of reason rather than the per se doctrine and pre suppose that IP licensing gives rise to pro-competitive effects in the market and not merely establishes market power for antitrust purposes. In 'rule of reason', authorities evaluate the precompetitive efficiencies of a restrictive business practice against its anti-competitive effects to see if it should be permitted or not, while in 'per se' concept the activity is always declared to be illegal, irrespective of the efficiencies generated by it.27 They don't believe that the market power imposes an obligation to license on the IP owner and in fact exclusivity from licensing encourages investments in licensed products and hence promotes innovation. ${ }^{28}$

In the case of Aspen ${ }^{29}$, the Supreme Court relied on Section 2 of the Sherman Act, 1890 to affirm the liability of the dominant firm from

25 Verizon Communications Inc v Law Offices of Curtis V Trinko, 540 US 398 (2004).

26 Byars v. Bluff City News Co., 609 F.2d 843, 855 (6th Cir. 1979).

27 See U.S. Department of Justice and Federal Trade Commission, Antitrust Guidelines for the Licensing of Intellectual Property (1995). available at: http://www.justice.gov/atr/public/guidelines/0558.htm

${ }^{28}$ Survey On Compulsory Licenses Granted By WIPO Member States To Address Anti-Competitive Uses Of Intellectual Property Rights, WORLD INTELlECTUAL PROPERTY ORGANISATION, 11 (2011) available athttp:// www.wipo.int/edocs/mdocs/mdocs/en/cdip_4/cdip_4_4_rev_study _inf_5.pdf.

${ }^{29}$ Aspen Skiing Co. v. Aspen Highlands Skiing Corp., 472 U.S. 585, 597 (1985). 
a refusal to deal and said it was necessary to give any consideration to the essential facilities doctrine (EFD). EFD implies when the owner of an essential facility is mandated to give access to it at reasonable prices. However, In Intel ${ }^{30}$, the court went on to quash the EF doctrine while finding that the theory is not disjunct from the need for a competitive relationship for liability under the Sherman Act. In the US, the liability for abuse of dominance under Section 2 of the Sherman Act, 1890 is imposed only when the refusal can be called exclusionary conduct. The US judgements, though divergent, endorse the view that refusal to co-operate with rivals amounts to anti-competitive conduct. ${ }^{31}$

The Courts played a cautious role in recognizing exceptions to the freedom of action of firms in Trinko $0^{32}$, because of the difficulty in identifying forced sharing and remedying the effects of anticompetitive conduct by firms. In Kodak $I^{33}$, the focus was on the exclusionary intent in the refusal to sell, which was deemed to be an illegal way of leveraging power in the aftermarket under Section 2 of the Sherman Act, 1890. Moreover, the court recognized that obtaining IPR through fraud and it's misuse by extending into other markets as the two restricting conditions on IPR. In Xerox ${ }^{34}$, the refusal was deemed to be within the scope of IPR and that in the absence of evidence of illegal tying, sham litigation or fraud, the IPR holder should not be subject to antitrust laws and held for abusing dominant position.

\section{Indian Scenario}

In India, the Competition Act holds an entity guilty of abuse, if it indulges in unfair pricing, limiting production of goods or services,

30 Intergraph Corp. v. Intel Corp., 195 F.3d 1346, 1353 (Fed. Cir. 1999).

31 R.Coco, Antitrust Liability For Refusal To License Intellectual Property: A Comparative Analysis and the International Setting, 12(1), MARQUETTE INTELLECTUAL PROPERTY LAW REVIEW, 29-31(2008).

32 Verizon Communications, Inc. v. Law Offices of Curtis V. Trinko, LLP 540 U.S. 398, 124 S.Ct. 872,157 L.Ed.2d 823 (2004).

33 Eastman Kodak v. Image Technical Services Inc. (90-1029), 504 U.S. 451 (1992).

34 SCM Corp. v. Xerox Corp 645 F.2d 1195 (2d Cir. 1981), cert. denied, 455 U.S. 1016 (1982). 
restricting technical development or denying market access. As per Section 4 of the Competition Act 2002, an enterprise is said to have a dominant position in the market when its economic strength allows it to hamper effective competition in the market by permitting it to behave independent of its customers, competitors and consumers. Though it has not been expressly stated, a refusal to license an IPR exclusively enjoyed by a dominant firm, can be construed as refusal to supply under the Competition Act, under the provision on limiting production of goods or restricting technical development to the prejudice of consumers or denial of market access. 35

In India, a four step process is followed, to ascertain if abuse of dominance is taking place. Firstly, the entities must be a group of interconnected enterprises. Secondly, the relevant market needs to be outlined. Thirdly, we need to ascertain if the company is dominant in the relevant market. And finally, it will have to be determined whether there is abuse of dominance. The Competition Act, 2002 does not stipulate that access would be a remedy against abuse of dominance arising from refusal to issue IPR licenses. However, some provisions may be interpreted to mean that it is possible to access IPR in the prevailing circumstances. As per Section 4(2) (c) of the Competition Act, 2002, when a dominant enterprise acts in a manner that has the effect of denial of market access, then it can be termed as abuse of dominance. This may be construed as including market access to a product that is protected by IP. Section 4 empowers Competition Commission of India (CCI) to issue remedial measures and this is akin to granting of compulsory license. Also, Section 27 of the Competition Act empowers the CCI to direct those engaged in abuse of dominance to desist from doing so by passing 'any other order' and hence the CCI may use this authority to ensure access to IPR, by compulsory licensing and avoiding abuse in exceptional circumstances. ${ }^{36}$

35 N. S. Chopra \& D. Muthappa, The Curious Case of Compulsory Licensing in India, 8(2), COMPETITION LAW INTERNATIONAL (2012).

36 Dr. R. Bhardwaj,Working Paper on Enforcement of Competition Law on Refusal to License of Intellectual Property Rights,SCHOOL OF COMPETITION LAW \& MARKET REGULATION, IICA (2015)at 11. 
A complaint may be made under Section 4(2)(a)(ii) of the Competition Act, alleging that the price is unaffordable for the public and manufacturers can make it available at cheaper prices. ${ }^{37}$ In the $M C X$ case ${ }^{38}$, the CCI noted that the IP owner is under no obligation to license the IP to third parties, but when certain essential facilities form a part of infrastructure held by the dominant player, compulsory licensing may be ordered. A number of factors such as resources, dependency on consumers, entry barriers, etc. were considered to analyze entry barriers and based on this, the CCI ordered National Stock Exchange to extend access to its software, since it was in the nature of an essential facility and barring access to it constituted abuse of dominance. In the case of HT Media v. T-Series ${ }^{39}$, abuse of dominance was highlighted from the perspective of excessive royalty being charged. It was held that the $2 \%$ royalty set by the copyright board is deemed to be a reasonable rate and charging anything in excess of it was unfair and anti-competitive.

\section{Comparative Analysis of US and EU Laws}

While Article 82 of the EC Treaty bars abuse of dominant position by an undertaking in a way that it affects trade, section 2 of the Sherman Acts condemns all kinds of attempts to monopolize any trade by a firm wielding market power. While the Sherman act only outlaws monopolization or attempts to do so, the EC Treaty envisages only the abuse of existing dominant positions. Both the legislations seek to regulate the market power, so it is not concentrated on anticompetitive practices of the firms. ${ }^{40}$

\footnotetext{
37 Bayer Corporation v. Natco Pharma Ltd., Order No. 45/2013

(Intellectual Property Appellate Board, Chennai).

${ }^{38}$ MCX v. NSE case no. 13/2009.

39 HT Media v. Super Cassettes Industries Limited CCI, Case No. 40 of 2011.

${ }^{40}$ M.C. Troberg, Differences Between The US And The EU In Antitrust Review Of Intellectual Property: A Comparative Analysis Of The Essential Facilities Doctrine, GLOBAL ANTI TRUST REVIEW, THE INTERDISCIPLINARY CENTRE FOR COMPETITION, LAW AND POLICY- QUEEN'S MARY UNIVERSITY, London, 56 (2011).
} 
In the US, the trend has been to shield IP against antitrust. The relevance of intent of the IP owner is also worth re-examining. The focus should be on the impact of the conduct and not the intent behind it. The guidelines attempt to balance IPR and competition law. The EU seems to be more anxious than their American counterparts about anticompetitive risks, which arise from the borderline use of IPR and the risk of losing innovation incentives. ${ }^{41}$

Though promulgated at different times, the US and EU, through Section 2 of the Sherman Act and Article 102 of Treaty on the Functioning of the European Union (TFEU) have attempted to protect citizens by preventing companies from indulging in unfair behavior. This social justice approach takes the shape of dominant firms being prevented from exploiting and impairing the opportunities of rivals. The EC has clarified that anti trust liability is not attracted only when there is harm, but when the abusive conduct hampers competition in a manner that is prejudicial to consumers and facilitates dominant firms to reap the gains by increasing prices, reducing output, restricting innovation and consumer choice. ${ }^{42}$ In the case of Leader Business v. EC Comissions ${ }^{43}$, the refusal by Microsoft to permit the French software being marketed in Canada cheaply to be imported to France, was deemed to be abusive conduct asit was a breach of article $82 .{ }^{44}$

Indian competition law does not offer any clarity on the practice of compulsory licensing of IPR, hence a proper understanding of the $\mathrm{EU}$ is essential to understand the mechanism. European courts impose a duty to issue licenses for IPR in exceptional cases. It is seen that the trend has moved from a liberal to an interventionist approach. The CCI should act with caution. This is important since

\footnotetext{
41 J.Tudor,Compulsory Licensing In The European Union,4 (2), G. MASON J. INT'L COM. LAW (2012).

42 Social Justice, Innovation And Antitrust Law by M. Maggiolino in A. Flanagan \& M.L. Montagnani, INTELlectuAl PROPERTY LAWECONOMIC AND SOCIAL JUSTICE PERSPECTIVES, 165 (2010).

43 Case T-198/98, available at http:/ / curia.europa.eu/juris/ show Pdf. jsf; jsessionid=9ea7d2dc30db0876d47c61024fd5a19d9b3bb2c90d38.e34Kaxi Lc3qMb40Rch0SaxqTbNz0?text=\&docid=104155\&pageIndex=0\&docla ng=en\&mode $=$ req\&dir $=\& o c c=$ first \&part $=1 \& c i d=47135$.

44 See J DAVIS, INTELLECTUAL PROPERTY LAW, 159-161(2nd edn, 2003).
} 
compulsory licensing may have a deterring effect on those desiring to enter the Indian market and IP firms may be compelled to shift elsewhere. This may reduce investment due to weak protection of IPR in issuing compulsory licenses. A better alternative would be to make reference vide the powers of CCI under Section 21 to the appropriate authority to determine if abuse of IPR has taken place or not. ${ }^{45}$

The common trait in all jurisdictions is the importance of determining market power and the examination of the unilateral conduct of enterprises. It is seen that in EU and India dominance by itself is not regarded as wrong, but only constitutes the first prong while analyzing abuse. Also, the US tends to focus on the intention of violation of competition law. The business justification also varies from meeting losses to extending benefits to consumers. While the US favors efficiency, the EU regards objective justification as important. The impact on consumers is also studied from different angles. While the US examines restriction in productivity and effect on prices, the EU seeks to ascertain consumer welfare. The list of activities called abusive are not exhaustive in EU and India since it tries to pigeonhole the different acts of abuse, but the US focuses on activities. The US also doesn't require pre-existing dominance to regard the conduct as being abusive, if market power can be achieved through its conduct. 46

\section{Conclusion}

Copyright must be treated by competition law in a unique manner. It is a product of an individual's intellectual creativity and the creator has moral rights over his work, thus issuing compulsory licenses on such a personal asset should be done with caution. Hence courts should pay heed to the creativity factor, when

45. See M. Delrahim, Forcing Firms To Share The Sandbox: Compulsory Licensing Of Intellectual Property Rights And Antitrust, Presented at the British Institute of International and Comparative Law London, England (May 10, 2004).

46 Raju, Interface between Competition law and Intellectual Property Rights: A Comparative Study of the US, EU and India, INTELLECTUAL PROPERTY RIGHTS: OPEN ACCESS (2014). 
imposing compulsory licenses. However, this means that works will be treated subjectively and hence it may be problematic to analyze the level of creativity, while trying to achieve a balance between property right and competition law.

The western perception has been to regard IPR as sacrosanct in nature and over regulation is feared for taking the color of protectionism. It is also viewed by some that the developing world is cautious of the fact that excessive competition can impair development. ${ }^{47}$ Compulsory licenses should be issued only to remedy anti-competitive conduct when the dominance of a firm is unquestionable, no alternative remedy exists and when interests in favor of the licensee are greater than the harm that may be caused to IPR holder's incentive to innovate. Compulsory licensing is not required merely due to commercial hardship. In the case of Oscart8, it was noted that the distribution chain is not that vital, since there can be other ways of selling paper and hence there was no abuse of dominance, merely because the newspaper used its own distribution chain to capture a large share of the market and other small enterprises could not compete with it

The deficiency with the EU and US approach is that no clear criteria has been laid down and courts have decided matters on a case to case basis. This inconsistency poses problems for other jurisdictions attempting to develop their approach on the lines of established cases. This means there are certain lacunae and some crucial factors may not be considered while deciding all cases. For instance, in Microsoft ${ }^{49}$, the EU paid no consideration to the development of new products and in fact, a new criterion for balancing incentives was developed.

IPR is inevitable in markets today. Since the tests have been redefined and relaxed over time, they have not been followed

47 C. Correa, Intellectual Property and Competition Law: Exploration of Some Issues of Relevance to Developing Countries, ICTSD IPRs and Sustainable Development Programme Issue Paper No. 21, International Centre for Trade and Sustainable Development, Geneva, Switzerland, 1-3 (2007).

48 Oscar Bronner $\mathrm{GmbH}$ \& Co. KG v. Mediaprint Zeitungs- und Zeitschriftenverlag GmbH \& Co. KG,Case C-7/97, 1998 E.C.R. I-7791.

49 Case T201/04, Microsoft Corp v Commission, 2007 ECR II03601 
uniformly. Even in similar circumstances, courts will use their discretion in deciding. The lack of fetters on IPR owners may lead to more chances of abuse and hence exceptional circumstances require intervention of competition law for compulsory licensing. There is a need to make a transition from the form-based to the effects-based approach, which focuses on the implications of anticompetitive practices on consumers, by analyzing the competitive harm. There is a strong need to make changes in the Competition Act, 2002and include the access to IP as a remedy for abuse of dominance, under Section 27. Effective channels must be instituted to deal with the cases of compulsory licensing and authorities should examine special circumstances, as it has been done in other jurisdictions, when ascertaining abuse. 